\title{
A lectin extracted from Citrullus colocynthis L. (Cucurbitaceae) inhibits digestive $\alpha$-amylase of Ectomyelois ceratoniae Zeller (Lepidoptera: Pyralidae)
}

\author{
S. Ramzi, A. Sahragard \\ Department of Plant Protection, University of Guilan, Rasht, Iran
}

\begin{abstract}
A lectin was extracted from seeds of Citrullus colocynthis (Cucurbitaceae) by column chromatography using Sepharose 4BGalactose and DEAE-Cellulose fast flow. The inhibitory effects of the extracted lectin on digestive $\alpha$-amylase of Ectomyelois ceratoniae larvae were studied using $\mathrm{pH}$, temperature, time of incubation and kinetic parameters. Different concentrations of extracted lectin, Citrullus colocynthis agglutinin (CCA), inhibited digestive amylolytic activity by $22-49 \%$. The highest inhibition was obtained at pH 8 and 9, which corresponds with the highest enzymatic activity in the control. The highest inhibition of $E$. ceratoniae $\alpha$-amylase was found at $40^{\circ} \mathrm{C}$, which corresponds with the optimal temperature for enzymatic activity. Timecourse experiments revealed the highest amylolytic activity at 20-40 min post-incubation, while the highest inhibition was found after 20 30 min. Kinetic analysis showed that incubation of $\alpha$-amylase with CCA significantly decreased $V_{\max }$, indicating non-competitive inhibition, but no statistical difference was found in the $K_{m}$ value. Our results indicated that CCA significantly inhibited activity of digestive $\alpha$-amylase in $E$. ceratoniae larvae, suggesting its possible application as a potential alternative control method against this pest.
\end{abstract}

Correspondence: Samar Ramzi, Department of Plant Protection, Faculty of Agriculture Science, University of Guilan, Rasht, Iran, 41637-1314.

Tel.: +98.0131.6690485 - Fax: +98.0131.6690281.

E-mail: samarramzi@yahoo.com

Key words: lectin, Citrullus colocynthis, Ectomyelois ceratoniae, $\alpha$-amylase.

Acknowledgements: this study was supported by a research grant behalf of research deputy in University of Guilan. The authors would like to thank Dr. Arash Zibaee for his assistance.

Received for publication: 9 May 2013.

Revision received: 21 August 2013.

Accepted for publication: 24 September 2013.

(C) Copyright S. Ramzi and A. Sahragard, 2013

Licensee PAGEPress, Italy

Journal of Entomological and Acarological Research 2013; 45:e20

doi:10.4081/jear.2013.e20

This article is distributed under the terms of the Creative Commons Attribution Noncommercial License (by-nc 3.0) which permits any noncommercial use, distribution, and reproduction in any medium, provided the original author(s) and source are credited.

\section{Introduction}

Ectomyelois ceratoniae Zeller (Lepidoptera: Pyralidae) is the major pest of pomegranate and some dried fruits that annually causes 15 90\% damage (Farazmand et al., 2008). Adults are gray moths with a wingspan of 9-12 mm. Larvae are pink, and hibernate in infested fruits on the soil surface. Adults lay their eggs on the pomegranate crown, and larvae hatch and feed on tissues around the pomegranate grains (Farazmand et al., 2008). Different control tactics, such as collection of infested fruits, removal of pomegranate crowns, and release of biocontrol agents, have been used to decrease damage by $E$. ceratoniae larvae (Farazmand et al., 2008).

Lectins are the heterogenous proteins that bind reversibly to monoor oligosaccharides (Peumans \& Van Damme, 1995). These molecules have been extracted from plants, fungi, bacteria and animals (Komath et al., 2006). In plants, lectins have a critical role in plant-insect coevolution (Chen, 2008). Various lectins have been extracted from plants, such as ASA I and ASA II from Allium sativum L., rice, legumes and cucurbitaceae (Peumans \& Van Damme, 1995; Van Damme, 1998; Zhu-Salzman et al., 2002; Jiang et al., 2006; Clement et al., 2010; Clement \& Venkatesh, 2010). Several studies have confirmed lectins as being insecticidal, and transgenic crops expressing lectin genes have been introduced in many economically important crops (Bell et al., 1999; de Oliveira et al., 2001). For example, the efficiency of Galanthus nivalis agglutinin (lectin) has been determined in potato (Down et al., 1996; Gatehouse et al., 1996), rice (Foissac et al., 2000; Nagadhara et al., 2004), maize (Wang et al., 2005), tobacco (Hilder et al., 1995), wheat (Stoger et al., 1999), tomato (Wu et al., 2000) and sugarcane (Sétamou et al., 2002, 2003; Li \& Romeis, 2009).

Citrullus colocynthis $\mathrm{L}$. is a medicinal plant belonging to the Cucurbitaceae family that is native to Iran and which is found in the southern and eastern regions (Tavakkol-Afshari et al., 2005). Fruits contain bitter glycosides that are used as drugs for gut and liver disorders. In addition to having anti-viral and anti-cancer properties, the crude fruit extract is effective in decreasing blood sugar (TavakkolAfshari et al., 2005). $\alpha$-amylase ( $\alpha$-1,4-glucan-4-glucanohydrolases; EC 3.2.1.1) is a hydrolytic enzyme that catalyzes the hydrolysis of endo$\alpha$-D-(1,4)-glucan linkages in glycogen and other related carbohydrates (Strobl et al., 1998; Franco et al., 2000). There are six different classes of $\alpha$-amylase inhibitors, which are known as lectin-like, knottin-like, cereal-type, Kunitz-like, c-purothionin-like, and thaumatin-like, that may be useful in pest control (Franco et al., 2002). These inhibitors show structural diversity leading to different modes of inhibition and different specificity against a diverse range of $\alpha$-amylases (Mehrabadi et al., 2010).

Although the effect of lectins on epithelial cells has been well elucidated, their inhibitory mechanisms on digestive enzymes remains 
unclear. Therefore, this study was conducted to determine the effective concentration of $C$. colocynthis lectin, Citrullus colocynthis agglutinin (CCA) on digestive $\alpha$-amylase of $E$. ceratoniae by considering $\mathrm{pH}$, temperature, time, kinetic parameters and gel electrophoresis.

\section{Material and methods}

\section{Insect rearing}

E. ceratoniae larvae were collected from pomegranate gardens in Yazd and fed on artificial diet containing wheat bran (100 g), yeast (3 $\mathrm{g})$, sugar $(10 \mathrm{~g})$, glycerine $(40 \mathrm{~mL})$ and water $(40 \mathrm{~mL})$. Adults were allowed to lay eggs, and newly hatched larvae were reared on artificial diet to reach fourth larval instar. Growth conditions were $28 \pm 2{ }^{\circ} \mathrm{C}, 85 \%$ relative humidity and photoperiod of $16 \mathrm{~L}: 8 \mathrm{D}$.

\section{Preparation of Sepharose 4B-Galactose column}

To prepare the column, $20 \mathrm{~mL}$ of Sepharose 4B was suspended in 40 $\mathrm{mL}$ of $0.5 \mathrm{M} \mathrm{Na}_{2} \mathrm{CO}_{2}$ (pH 11.0), then $2 \mathrm{~mL}$ of divinylsulphone was added to the suspension and the mixture was incubated for $70 \mathrm{~min}$ at room temperature with gentle agitation. After activation, $500 \mathrm{mg}$ of galactose was added in $50 \mathrm{ml} 0.5 \mathrm{M} \mathrm{Na}_{2} \mathrm{CO}_{2}(\mathrm{pH} \mathrm{11.0)}$ and the suspension were re-incubated for an additional $12 \mathrm{~h}$. The sorbent was washed with water; the unbound arm was blocked with b-mercaptoethanol-containing buffer, and then packed into a $1.5 \times 30 \mathrm{~cm}$ column. The sorbent was equilibrated with Tris- $\mathrm{HCl}(0.1 \mathrm{M})$ and used for the affinity purification of CCA.

\section{Purification of Citrullus colocynthis agglutinin}

Seeds of $C$. colocynthis were ground to fine powder using a mill. The dry powder was incubated in phosphate buffer $(0.1 \mathrm{M} \mathrm{pH} \mathrm{7.1)}$ for approximately $20 \mathrm{~h}$ at $4^{\circ} \mathrm{C}$. The mixture was then centrifuged at $4000 \mathrm{~g}$ for $20 \mathrm{~min}$, and the remaining debris removed by passing the supernatant through filter paper (Whatman No. 4) (Hamshou et al., 2010). Supernatant was precipitated by $0-60 \%$ concentrations of ammonium sulfate and centrifuged at $4000 \mathrm{~g}$ for $20 \mathrm{~min}$. Debris was eluted in Tris$\mathrm{HCl}$ buffer ( $0.1 \mathrm{M}, \mathrm{pH} 7)$ and dialyzed in the same buffer overnight (de Oliveira et al., 2011). Affinity chromatography was performed on a Sepharose 4B-galactose column equilibrated with Tris-HCl buffer $(0.1$ $\mathrm{M}, \mathrm{pH}$ 7). After loading the extract, the affinity column was washed with buffer and the bound lectin was eluted with $20 \mathrm{mM}$ of 1,3-diaminopropane (DAP) (Hamshou et al., 2010). Fractions showing the highest protein content were pooled and used for the next step. The lectin fractions obtained after the first affinity chromatography were loaded on an anion exchange chromatography column of DEAE-Cellulose fast flow, equilibrated with DAP (Hamshou et al., 2010). After washing with DAP, the lectin was eluted using Tris- $\mathrm{HCl}(0.1 \mathrm{M}, \mathrm{pH} 7.0)$ containing $0.5 \mathrm{M}$ $\mathrm{NaCl}$. Finally, the lectin fractions were dialyzed against water and lyophilized. The purity of the lectin was analyzed by SDS-PAGE.

\section{Sample preparation}

E. ceratoniae larvae ( $4^{\text {th }}$ instars $)$ were randomly selected and dissected under a stereo-microscope in ice-cold saline solution $(10 \mathrm{mM})$. Larval bodies were cut separately using a scalpel and the midgut exposed by removal of fat bodies and other undesirable organs. The midgut was separated from the larval body and rinsed in ice-cold distilled water. The mixture was placed in a pre-cooled homogenizer and ground before centrifugation. Equal portions of larval midgut and distilled water were used to obtain a desirable concentration of the enzyme (WN). Homogenates were separately transferred to $1.5-\mathrm{mL}$ centrifuge tubes and centrifuged at $25,000 \mathrm{~g}$ for $20 \mathrm{~min}$ at $4^{\circ} \mathrm{C}$. The supernatants were pooled and stored at $-20 \mathrm{C}$ for subsequent analyses.
All the experiments were conducted immediately following sample preparation.

\section{$\alpha$-amylase assay}

The method described by Bernfeld (1955) was used to assay $\alpha$-amylase activity. Ten microliters of the homogenate was incubated for 30 min at $35^{\circ} \mathrm{C}$ with $50 \mathrm{~L}$ of phosphate buffer $(0.02 \mathrm{M}, \mathrm{pH} 7.1)$ and $20 \mathrm{l}$ of soluble starch (1\%) as substrate. The reaction was stopped by addition of dinitrosalicylic acid (DNS, $80 \mu \mathrm{L}$ ) and heated in boiling water for 10 min prior to reading the absorbance at $540 \mathrm{~nm}$. One unit of $\alpha$-amylase activity was defined as the amount of enzyme required to produce $1 \mathrm{mg}$ maltose in $30 \mathrm{~min}$ at $35^{\circ} \mathrm{C}$. The negative control contained all reaction mixtures with pre-boiled enzyme (for $15 \mathrm{~min}$ ) to prove enzyme presence in the samples.

\section{Inhibition of $\alpha$-amylase by different concentrations of Citrullus colocynthis agglutinin}

To find possible inhibition of the digestive $\alpha$-amylase, $50 \mu \mathrm{L}$ of PBS ( $0.02 \mathrm{M}, \mathrm{pH} 7.1$ ), $20 \mu \mathrm{L}$ of starch $1 \%$ and $20 \mu \mathrm{L}$ of different concentrations of lectin $(0,0.1,0.5,1,1.5$ and $2 \mathrm{mg} / \mathrm{mL})$ were incubated for $5 \mathrm{~min}$. Then, $10 \mu \mathrm{L}$ of the enzyme was added and the reaction continued as described above. Blanks were run containing PBS, starch 1\% and each concentration of lectin.

\section{Effect of $\mathrm{pH}$ on $\alpha$-amylase inhibition by Citrullus colocynthis agglutinin}

Effect of $\mathrm{pH}$ on CCA inhibition on $\alpha$-amylase was determined at different $\mathrm{pH}$ values using Tris-HCl buffer $(20 \mathrm{mM})$ at $\mathrm{pH}$ levels of $3,4,5$, $6,7,8,9,10,11$ and 12 . The enzyme activity was assayed after incubation of the reaction mixture containing Tris- $\mathrm{HCl}$ buffer (at a given $\mathrm{pH}$ value), starch $1 \%$, CCA (2 mg/mL) and midgut homogenate. Controls were run at each $\mathrm{pH}$ value with midgut $\alpha$-amylase alone as a control. Other steps were carried out as previously described.

\section{Effect of temperature on $\alpha$-amylase inhibition by Citrullus colocynthis agglutinin}

To obtain the effect of temperature on $\alpha$-amylase inhibition by CCA, the reaction mixture containing Tris- $\mathrm{HCl}(20 \mathrm{mM} \mathrm{pH}, 9)$, starch $1 \%$, CCA $(2 \mathrm{mg} / \mathrm{mL})$ and enzyme was incubated at different temperatures of $15,20,25,30,35,40,45,50$ and $60^{\circ} \mathrm{C}$. A control was carried out without the inhibitor. Other steps were carried out as previously described.

\section{Time-course inhibition of $\alpha$-amylase by Citrullus colocynthis agglutinin}

Time-course inhibition of $\alpha$-amylase by CCA was carried out by incubating the enzyme extract with CCA and other reaction constituents in Tris- $\mathrm{HCl}$ buffer $(20 \mathrm{mM}, \mathrm{pH} 9)$ at $40^{\circ} \mathrm{C}$ for different time intervals of 10 , $20,30,40,50$ and $60 \mathrm{~min}$. Other steps were carried out as previously described.

\section{Kinetic studies}

Kinetic parameters of inhibition and control were carried out with increasing concentrations of starch as the substrate (0.5-2.0\%) in the presence of CCA $(2 \mathrm{mg} / \mathrm{mL})$. Lineweaver-Burk plot analysis was done based on the data to find affinity of enzyme to substrate $\left(K_{m}\right)$ and velocity of enzyme $\left(V_{\max }\right)$ values.

\section{Inhibition in non-denaturing PAGE}

Enzyme extract was pre-incubated with different concentrations of CCA for $30 \mathrm{~min}$ at $30^{\circ} \mathrm{C}$, then the remaining $\alpha$-amylase activity was determined by polyacrylamide gel electrophoresis. PAGE was carried 
out using the procedures described by Laemmli (1970). Concentrations of resolving and stacking gel were 12 and 4\%, respectively. Electrophoresis was conducted at a voltage of $70 \mathrm{~V}$ until the blue dye reached the bottom of the slab gel. The gel was rinsed with distilled water and washed with $1 \%(\mathrm{v} / \mathrm{v})$ of Triton X-100. The gel was then immersed in a solution of PBS (0.02 M pH 7.1) containing $1 \%$ starch, $10 \mathrm{mM}$ of $\mathrm{NaCl}$ and $2 \mathrm{mM}$ of CaCl . Finally, it was stained with solutions of $1.3 \% \mathrm{I} 2$, and $3 \% \mathrm{KI}$ to obtain white bands with dark backgrounds.

\section{Protein assay}

Protein concentrations were assayed according to the method described by Lowry et al. (1951).

\section{Statistical analysis}

All data were compared by one-way analysis of variance (ANOVA) followed by Tukey's test at the $\mathrm{P} \leq 0.05$ level.

\section{Results}

In the current study, a lectin with a molecular weight of $14.5 \mathrm{kDa}$ was extracted from seeds of $C$. colocynthis (Figure 1), which significantly inhibited digestive $\alpha$-amylase of $E$. ceratoniae by $22-49 \%$ (Figure $2 A$ ). Also, incubation of larval midgut homogenate with $2 \mathrm{mg} / \mathrm{ml}$ of CCA decreased sharpness of amylolytic isozymes (Figure 2B). The protein was able to inhibit $50 \%$ of total amylolytic activity both in assay conditions and with gel electrophoresis (Figure 2).

The effect of $\mathrm{pH}$ on $\alpha$-amylase inhibition by CCA is shown in Figure

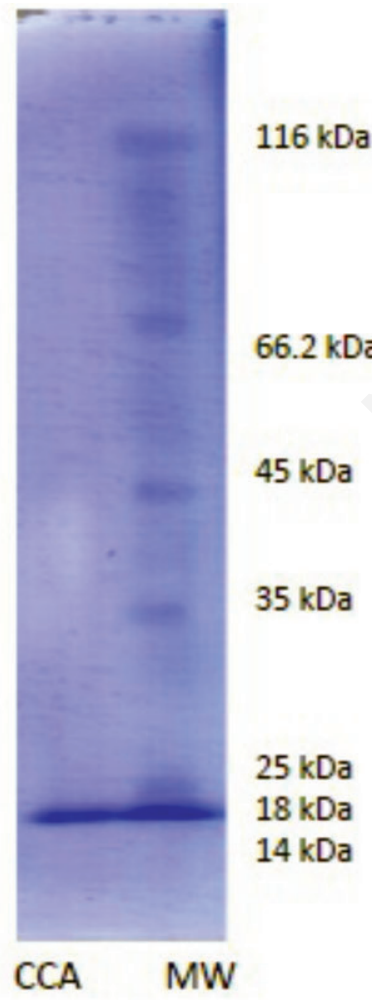

Figure 1. SDS-PAGE showing purity and molecular weight of the purified lectin. CCL, Citrullus colocynthis lectin; MM, molecular weight.
3A. There were significant differences among $\mathrm{pH}$ levels $(\mathrm{F}=5.43$, $\mathrm{P}=0.004)$, with the highest inhibition at $\mathrm{pH} 8$; there was slightly less inhibition, although not different, at $\mathrm{pH} 9$ (Figure $3 \mathrm{~A}$ ). The optimal $\mathrm{pH}$ of the $\alpha$-amylase (control) was observed at $\mathrm{pH} 8$ and 9 (Figure 3B) $(\mathrm{F}=18.56$, Pr $>\mathrm{F}: 0.0001)$. In the case of temperature, the highest inhibition of $\alpha$-amylase was found at $40^{\circ} \mathrm{C}$, while the optimal temperature was observed to be between $20-45^{\circ} \mathrm{C}$ (Figure 4; Pr>F: 0.004, $\mathrm{F}=5.02$; Pr>F: 0.0001, F=21.21).

Results revealed the highest inhibition of the enzyme at 20-30 min of post-incubation (Figure 5A). In the control, the highest enzymatic activity was observed at 20-40 min of post-incubation (Figure 5B). There was a correlation between the times of the highest enzymatic activity and the highest inhibition.

In this study, $V_{\max }$ and $K_{m}$ values for the control were found to be 0.46

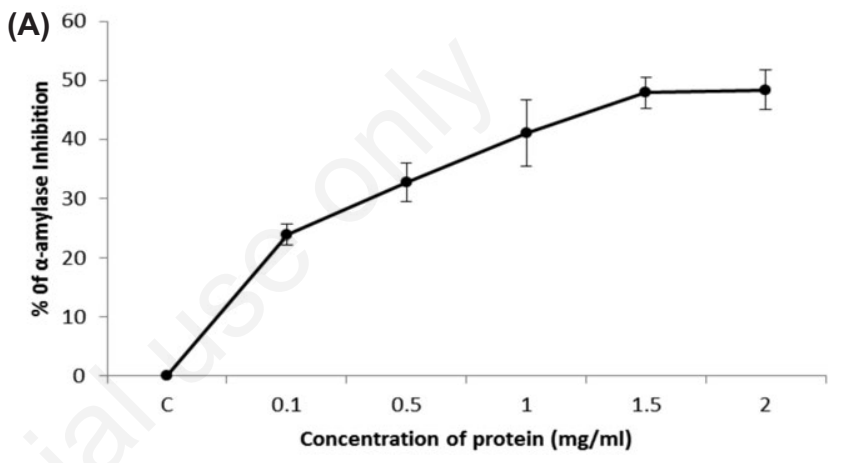

(B)



A1

\section{A2

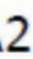


0D/min and $1.08 \%$, respectively (Figure 6) while these parameters were $0.155 \mathrm{OD} / \mathrm{min}$ and $0.96 \%$ in the incubation of the enzyme with CCA (Figure 6). Kinetic analysis showed that incubation of enzyme with inhibitor significantly decreased the $V_{\max }$ parameter, indicating non-competitive inhibition. Although a change in $K_{\mathrm{m}}$ value was observed, it was not statistically different.

\section{Discussion and conclusions}

One of the promising alternatives for insect control is the use of biotechnological processes to provide resistant varieties of host plants. There are several genes identified to do so, such as Bt toxins, digestive enzyme inhibitors, chitinases and lectins (Bishop et al., 2000; Sales et al., 2000; Carlini \& Grossi-de-Sa, 2002; Bertrand et al., 2003; Bellincampi et al., 2004; Haq et al., 2004; de Azevedo Pereira et al., 2006). Several classes of plant proteins have been discovered and characterized, including lectins, ribosome-inactivating proteins, and protease and $\alpha$-amylase inhibitors, which have shown insecticidal effects on different insect pests (Ishimoto et al., 1989; Ryan, 1990; Chrispeels et al., 1998; Gatehouse \& Gatehouse, 1998; Ussuf et al., 2001). There are six different classes of $\alpha$-amylase inhibitors: lectin-like, knottinlike, cereal-type, Kunitz-like, c-purothionin-like, and thaumatin-like, which may be useful in pest control (Franco et al., 2000; Bonavides et al., 2007). Suzuki et al. (1994) believed that these inhibitors had a high degree of sequence homology and specificity. Different studies have also been carried out determining types of lectin-like inhibitors and

(A)


Figure 3. A and B) $\mathrm{pH}$ dependency of $E$. ceratoniae $\alpha$-amylase inhibition by $C$. colocynthis lectin $(2 \mathrm{mg} / \mathrm{mL})$ versus the control. Reaction conditions were Tris- $\mathrm{HCl}$ buffer $(20 \mathrm{mM}$, pHs 6-12) at $30^{\circ} \mathrm{C}$. Different letters indicate statistical difference among values, Tukey's test $(\mathrm{P} \leq \mathbf{0 . 0 5})$. their effects on $\alpha$-amylases of insects (Grossi-de-Sá \& Chrispells, 1997; Da Silva et al., 2000; Yamada et al., 2001). $\alpha$-AI1 inhibited digestive $\alpha$ amylases from Callosobruchus maculatus Fabricius (Coleoptera: Bruchidae) and $C$. chinensis, but it had no inhibitory effect against Zabrotes subfasciatus Boheman (Coleoptera: Chrysomelliade) amylase. Another inhibitor was $\alpha$-AI2, which was not able to inhibit the first three $\alpha$-amylases of assayed bruchids, but which inhibited $\alpha$-amylase of Z. subfaciatus (Grossi-de-Sá \& Chrispells, 1997; Da Silva et al., 2000; Yamada et al., 2001). Mirkov et al. (1994) believed that these types of inhibition indicated an evolutionary relationship with phyto-hemagglutinnins and arcelins.

Temperature and $\mathrm{pH}$ are the two critical factors in biochemical reactions that could affect both activity and inhibitory mechanisms. In the current study, the highest inhibition of $\alpha$-amylase occurred at an alkaline $\mathrm{pH}$, where the highest enzymatic activity was observed. However, in the case of Eurygaster integriceps Puton (Hemiptera: Scutelleridae), the highest inhibition by triticale extraction was observed at $\mathrm{pH} 5$ and 6 for both salivary and midgut $\alpha$-amylases (Mehrabadi et al., 2010; Mehrabadi et al., 2012). Several authors have confirmed a pH-dependent interaction between amylases and inhibitors (Powers \& Whitaker, 1977; Valencia et al., 2000; Mehrabadi et al., 2010, 2012). Extracted $\alpha$ AI from Phaseolus vulgaris $\mathrm{L}$. inhibited porcine pancreatic $\alpha$-amylase at $\mathrm{pH} 5.5$, an effect that varied at $\mathrm{pH} 4.5$ to 5.5 , depending on the strain of bean used (Barbosa et al., 2010). Since the gut lumen of insects is the place where the interaction between $\alpha$-amylase and inhibitors occurs, the $\mathrm{pH}$ showing the highest inhibition may reflect the fact that the $\mathrm{pH}$ of insect midgut is alkaline (Ranjbar et al., 2011). Since $\alpha$-amylase may have the highest activity under such conditions, it should be more inhibited if CCA
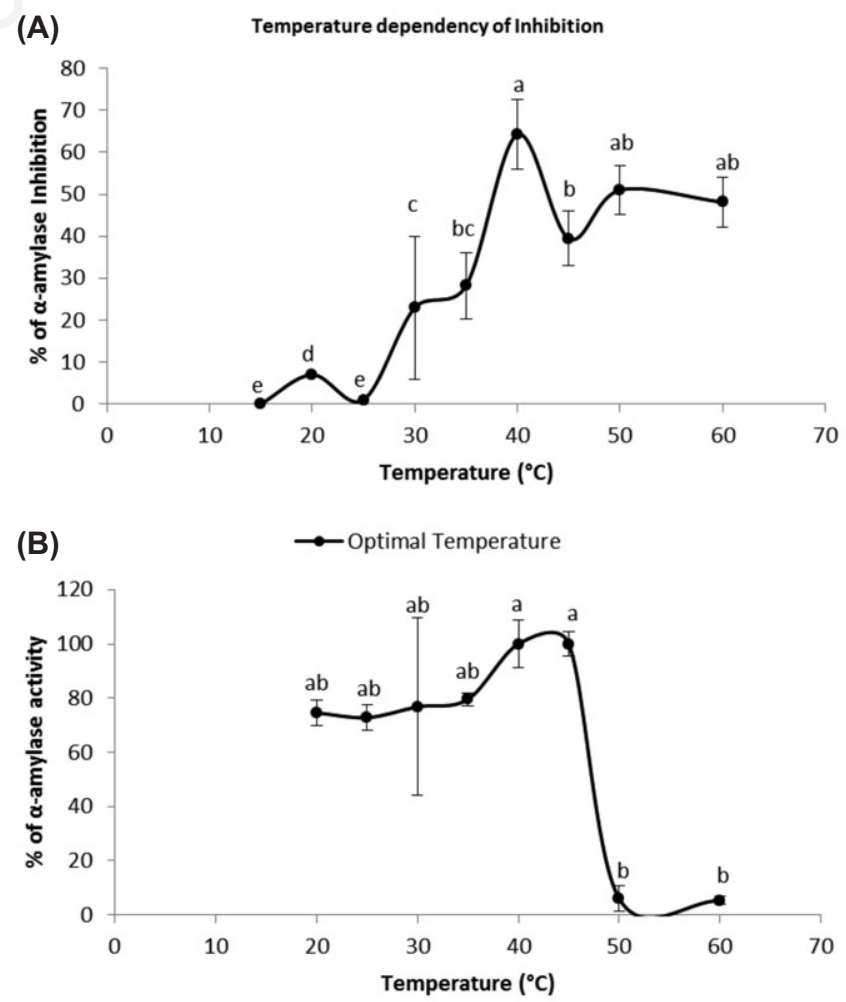

Figure 4. A and B) Effect of temperature on $E$. ceratoniae $\alpha$-amylase inhibition by $C$. colocynthis lectin $(2 \mathrm{mg} / \mathrm{mL})$ versus control. Reaction conditions were Tris- $\mathrm{HCl}$ buffer $(20 \mathrm{mM}, \mathrm{pH} 8)$ at different temperatures $\left({ }^{\circ} \mathrm{C}\right)$. Different letters indicate statistical difference among values, Tukey's test $(\mathbf{P} \leq \mathbf{0 . 0 5})$. 


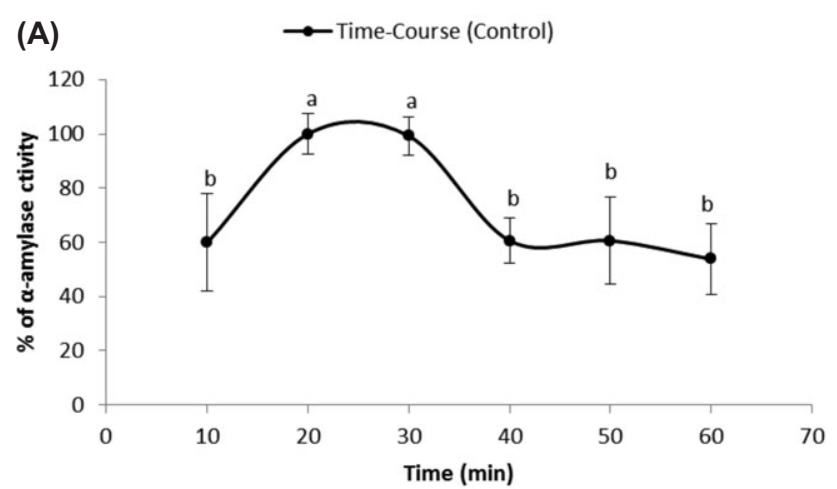

(B) $\rightarrow$ Time-Course $(2 \mathrm{mg} / \mathrm{ml})$

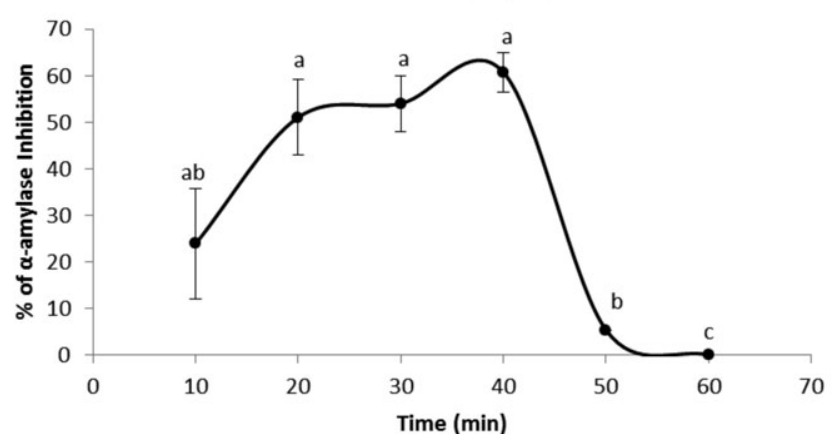

Figure 5. A and B) Time course inhibition of E. ceratoniae $\alpha$-amylase by $C$. colocynthis lectin $(2 \mathrm{mg} / \mathrm{mL})$. Midgut samples were preincubated with inhibitor in $20 \mathrm{mM}$ Tris- $\mathrm{HCl}$ buffer $(\mathrm{pH} \mathrm{8})$ at $30^{\circ} \mathrm{C}$, after which enzyme was added and reaction was recorded at the given time intervals. Different letters indicate statistical difference among values, Tukey's test $(P \leq 0.05)$.

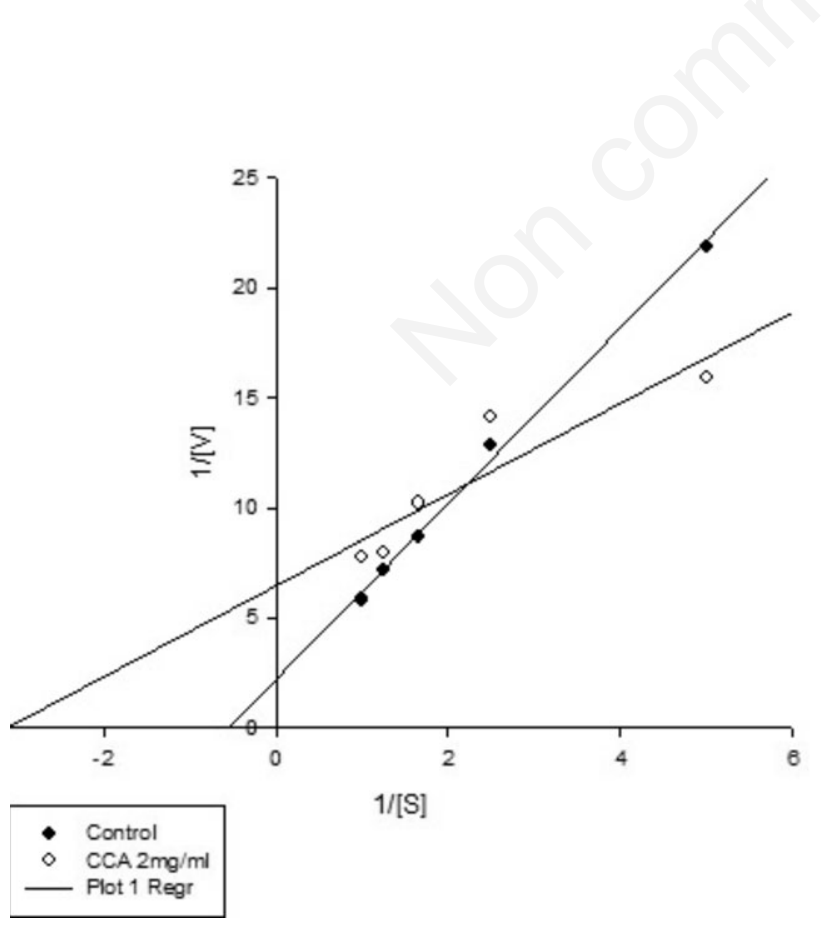

Figure 6. Effect of proteinaceous $\alpha$-amylase inhibitor from $C$. colocynthis on amylolytic activity in the midgut of $E$. ceratoniae by Lineweaver-Burk plot versus control. is available at an appropriate concentration. This phenomenon has been described in other studies (Biggs \& McGregor, 1996; Valencia et al., 2000; Mehrabadi et al., 2010, 2012). The observed specific temperature for inhibition and activity of $\alpha$-amylase could reflect the environmental temperature where $E$. ceratoniae, a poikilothermic organism, lives. Regarding incubation time for inhibition, Mehrabadi et al. (2010) demonstrated the maximum amylolytic inhibition in the midgut of $E$. integriceps by triticale extract after 20-30 min post-incubation. Similar results were found by Marshall \& Lauda (1975) and LeBerre-Anton et al. (1997).

Lineweaver-Burk analysis is used to indicate the behavior and inhibition mechanism of an enzyme. $V_{\max }$ and $K_{m}$ are the two main parameters in these calculations showing the highest velocity of enzyme $\left(V_{\max }\right)$ and affinity of enzyme to substrate $\left(\mathrm{K}_{\mathrm{m}}\right)$. Additionally, $K_{m}$ may show affinity of an inhibitor to enzyme or enzyme-substrate complex. Higher $V_{\max }$ and lower $K_{m}$ shows the desirable values for better performance of an enzyme. In the present study, incubation of the enzyme with inhibitor significantly decreased $V_{\max }$ value, indicating non-competitive inhibition. With this kind of inhibition, the inhibitor binds to a specific site of the enzyme and causes a type of conformation (Eisenthal \& CornishBowden, 1974). This conformation does not prevent substrate binding but prevents the enzyme from converting the bound substrate to product. This kind of inhibition has been reported by several authors (Marshall \& Lauda, 1975; LeBerre-Anton et al., 1997; Mehrabadi et al., 2010).

The present study uncovers a new lectin protein with $\alpha$-amylase inhibitory properties that may be used in the genetic modification of crops by gene encoding to create transgenic plants showing resistance against insect pests. Besides the in vivo effects of CCA on the digestive physiology of $E$. ceratoniae, we found that CCA significantly disrupts digestion of food in this insect. Determination of a CCA-encoding gene and its transferral to plants may therefore lead to a resistant variety of host plant. These findings could ultimately be used to design specific bio-insecticides for use against economically important pests.

\section{References}

BARBOSA A.E.A.D, ALBUQUERQUE E.V.S., SILVA M.C.M., SOUZA D.S.L., OLIVEIRA-NETO O.B., VALENCIA A.V., et al., 2010 - R $\alpha \mathrm{e}-$ seAarcmhayrtilcalese inhibitor-1 gene from Phaseolus vulgaris expressed in Coffea arabica plants inhibits $\alpha$-amylases from the coffee berry borer pest. - BMC Biotechnol. 10: 44.

BELL H.A., FITCHES E., DOWN R.E., MARRIS G.C., EDWARDS J.P., GATEHOUSE J.A. 1999 - The effect of snowdrop lectin (GNA) delivered via artificial diet and transgenic plants on Eulophus pennicornis (Hymenoptera: Eulophidae), a parasitoid of the tomato moth Lacanobia oleracea (Lepidoptera: Noctuidae). - J. Insect. Physiol. 45: 983-991.

BELLINCAMPI D., CAMARDELLA L., DELCOUR J.A., DESSEAUX V., D'OVIDIO R., DURANDA E.G., GEBRUERS K., GIOVANE A., JUGE N., 2004 - Potential physiological role of plant glycosidase inhibitors. - Biochim. Biophys. Acta. 1696: 265-274.

BERNFELD P., 1955 - Amylases, $\alpha$ and . - Meth. Enzymol. 1:149-158.

BERTRAND B., GUYOT B., ANTHONY F., LASHERMES P., 2003 - Impact of the Coffea canephora gene introgression? on beverage quality of C. arabica. - Theoret. Appl. Gen. 107: 387-394.

BIGGS D.R., MCGREGOR P.G., 1996 - Gut pH and amylase and protease activity in larvae of the New Zealand grass grub (Costelyra zealandica; Coleoptera: Carabaeidae) as a basis for selecting inhibitors. - Insect. Biochem. Mol. Biol. 26: 69-75.

BISHOP J.G., DEAN A.M., MITCHELL-OLDS T., 2000 - Rapid evolution in plant chitinases: Molecular targets of selection in plant-pathogen coevolution. - PNAS 97: 5322-5327.

BONAVIDES K.B., PELEGRINI P.B., LAUMANN R.L., GROSSI-DE-SÁ M.F., 
BLOCH J.R.C., MELO J.A.T., et al., 2007 - Molecular identification of four different $\alpha$-amylase inhibitors from Baru (Dipteryxalata) seeds with activity toward insect enzymes. - J. Biochem. Mol. Biol. 40: 494-500.

CARLINI C.R., GROSSI-DE-SA M.F., 2002 - Plant toxic proteins with insecticidal properties. A review on their potentialities as bioinsecticides. - Toxicon. 40:1 515-1539.

CHEN C.M., 2008 - Inducible direct plant defense against insect herbivores: a review. - Insect. Sci. 15: 101-114.

CHRISPEELS M.J., GROSSI-DE-SA M.F, HIGGINS T.J.V., 1998 - Genetic engineering with alpha-amylase inhibitors makes seeds resistant to bruchids. Seed Sci. Res. 8: 257-263.

CLEMENT F., PRAMOD S.N., VENKATESH Y.P., 2010 - Identity of the immunomodulatory proteins from garlic (Allium sativum) with the major garlic lectins or agglutinins. - Intern. Immunopharmacol. 10: 316-324.

CLEMENT F., VENKATESH Y.P., 2010 - Dietary garlic (Allium sativum) lectins, ASA I and ASA II, are highly stable and immunogenic. Intern. Immunopharmacol. 10: 1161-1169.

DA SILVA M.C.M., GROSSI-DE-SÁ M.F., CHRISPEELS M.J., TOGAWA R.C., NESHICH, G., 2000 - Analysis of structural and physico-chemical parameters involved in the specificity of binding between $\alpha$ amylases and their inhibitors. - Protein. Eng. 13: 167-177.

DE AZEVEDO PEREIRA R., NOGUEIRA BATISTA J.A., DA SILVA M.C., BRILHANTE DEOLIVEIRA NETO 0., ZANGRANDO FIGUEIRA E.L., VALENCIA JIMENEZ A., et al., 2006 - An alpha-amylase inhibitor gene from Phaseolus coccineus encodesa protein with potential for control of coffee berry borer (Hypothenemus hampei). Phytochem. 67: 2009-2016.

DE OLIVEIRA C.F.R., LUZ L.A., PAIVA P.M.G., COELHO L.C.B.B., MARANGONIA S., MACEDO M.L.R., 2011 - Evaluation of seed coagulant Moringaoleiferalectin (cMoL) as a bioinsecticidal tool with potential for the control of insects. - Proc. Biochem. 46: 498-504.

DOWN R.E., GATEHOUSE A.M.R., HAMILTON W.D.O., GATEHOUSE J.A., 1996 - Snowdrop lectin inhibits development and decreases fecundity of the glasshouse potato aphid (Aulacorthum solani) when administered in vitro and via transgenic plants both in laboratory and glasshouse trials. - J. Insect. Physiol. 42: 1035-45.

EISENTHAL R., CORNISH-BOWDEN A., 1974 - The direct linear plot: a new graphical procedure for estimating enzyme kinetic parameters. - Biochem. J. 139: 715-720.

FARAZMAND H., SIRJANI M., TOUFA K., 2008 - Effect of crown coverage in decreasing of carob moth damages in Khorasan-Razavi province. - $18^{\text {th }}$ Iranian Plant Protection Congress, Bu'ali-Sina University: 318.

FOISSAC X., LOC N.T., CHRISTOU P., GATEHOUSE A.M.R., GATEHOUSE J.A., 2000 - Resistance to green leafhopper (Nephotettix virescens) and brown planthopper (Nilaparvata lugens) in transgenic rice expressing snowdrop lectin (Galanthus nivalis agglutinin; GNA). J. Insect Physiol. 46: 573-83.

FRANCO O.L., RIDGEN D.J., MELO F.R., BLOCH C J.R., SILVA C.P., GROSSI-DE-SA M.F., 2000 - Activity of wheat $\alpha$-amylase inhibitors towards bruchid $\alpha$-amylases and structural explanation of observed specificities. - Eur. J. Biochem. 267: 2166-2173.

GATEHOUSE A.M.R., DOWN R.E., POWELL K.S., SAUVION N., RAHBÉ Y., NEWELL C.A., 1996 - Transgenic potato plants with enhanced resistance to the peach-potato aphid Myzus persicae. - Entomol. Exp. Appl. 79: 295-307.

GATEHOUSE A.M.R., GATEHOUSE J.A., 1998 - Identifying proteins with insecticidal activity: use of encoding genes to produce insectresistant transgenic crops. Pest. Sci. 52: 165-175.

GROSSI-DE-SÁ M.F., CHRISPEELS M.J., 1997 - Molecular cloning of bruchid (Zabrotessub fasciatus) $\alpha$-amylase cDNAand interaction of the expressed enzyme with bean $\alpha$-amylase inhibitors. - Insect. Biochem. Mol. Biol. 27: 271-281.
HAMSHOU M., SMAGGHE G., VAN DAMME E.J.M., 2010 - Entomotoxic effects of fungal lectin from Rhizoctonia solani towards Spodoptera littoralis. - Fung. Biol. 114: 34-40.

HAQ S.K., ATIF S.M., KHAN R.H., 2004 - Protein proteinase inhibitor genes in combat against insects, pests, and pathogens: natural and engineered phytoprotection. - Arch. Biochem. Biophysics. 431: 145-159.

HILDER V.A., POWELL K.S., GATEHOUSE A.M.R., GATEHOUSE J.A., GATEHOUSE L.N., SHI Y., 1995 - Expression of snowdrop lectin in transgenic tobacco plants results in added protection against aphids. - Transgen. Res. 4: 18-25.

ISHIMOTO M., KITAMURA K., 1989 - Growth inhibitory effects of an aamylase inhibitor from kidney bean, Phaseolus vulgaris (L.) on three species of bruchids (Coleoptera: Bruchidae). - Appl. Entomol. Zool. 24: 281-286.

JIANG J.F., HAN Y., XING L.J., XU Y.Y., XU Z.H., CHONG K., 2006 Cloning and expression of a novel cDNA encodinga mannose-specific jacalin-related lectin from Oryza sativa. Toxicon 47: 133-139.

KOMATH S.S., KAVITHA M., SWAMY M.J., 2006 - Beyond carbohydrate binding: new directions in plant lectin research. - Org. Biomol. Chem. 4: 973-988.

LAEMMLI U.K., 1970 - Cleavage of structural proteins during the assembly of the head of bacteriophage T4. - Nature. 227: 680-685.

LE BERRE-ANTON V., BOMPARD-GILLES C., PAYAN F., ROUGE P., 1997 - Characterization and functional properties of the alpha-amylaseinhibitor (alpha A-1) from kidney bean (Phaseolus vulgaris) seeds. - Biochim. Biophys. Acta. 1343: 31-40.

LI Y., ROMEIS J., 2009 - Impact of snowdrop lectin (Galanthus nivalis agglutinin; GNA) on adults of the green lacewing, Chrysoperla carnea. - J. Insect. Physiol. 55:136-43.

LOWRY O.H., ROSEBROUGH N.J., FARR A.L., RANDALL R.J., 1951 Protein measurement with the Folin phenol reagent. - J. Biol. Chem. 193: 265-75.

MARSHALL J.J., LAUDA C.M., 1975 - Purification and properties of phaseolamin, an inhibitor of alpha $\alpha$-amylase, from the kidney bean Phaseolus vulgaris. - J. Biol. Chem. 250: 8030-8037.

MEHRABADI M., BANDANI A.R., MEHRABADI R., ALIZADEH H., 2012 Inhibitory activity of proteinaceous a-amylase inhibitors from Triticale seeds against Eurygaster integriceps salivary a-amylases: interaction of the inhibitors and the insect digestive enzymes. Pest. Biochem. Physiol. 102: 220-228.

MEHRABADI M., BANDANI A.R., SAADATI F., 2010 - Inhibition of Sunn pest, Eurygaster integriceps, $\alpha$-amylases by $\alpha$-amylaseinhibitors (T$\alpha \mathrm{AI})$ from Triticale. - J. Insect. Sci. 10: 179.

MIRKOV T.E., WAHLSTROM J.M., HAGIWARA K., FINARDI-FILHO F., KJEMTRUP S., CHRISPEELS M.J., 1994. -Evolutionary relationship among proteins in the phytohemagglutininarcelin-alpha-amylase inhibitor family of the common bean and its relatives. - Plant Mol. Biol. 26: 1103-1113.

NAGADHARA D., RAMESH S., PASALU I.C., KONDAL R.Y., SARMA N.P., REDDY V.D., 2004 - Transgenic rice plants expressing the snowdrop lectin gene (GNA) exhibit high-level resistance to the white backed planthopper (Sogatella furcifera). - Theor. Appl. Genet. 109: 13991405.

PEUMANS W.J., VAN DAMME E.J.M., 1995 - The role of lectins in plant defense. - Histochem. J. 27: 253-271.

POWERS J.R., WHITAKER J.R., 1977 - Effect of several experimental parameters on combination of red kidney bean (Phaseolus vulgaris) $\alpha$-amylase inhibitor with porcinepancreatic $\alpha$-amylase. - J. Food. Biochem. 1: 239-260.

RANJBAR M., SENDI J. J., ZIBAEE A., 2011 - Proteolytic activity in the midgut of Ectomyeloisceratoniae Zeller (Lepidoptera: Pyralidae), Pomegranate carob moth. - Invert. Surv. J. 8: 132-142.

RYAN C.A., 1990 - Proteinase inhibitors in plants: genes for improving 
defenses against insects and pathogens. - Ann. Rev. Phytopathol. 28: 425-449.

SALES M.P., GERHARDT I.R., GROSSI-DE-SA M.F., XAVIER-FILHO J., 2000 - Do legume storage proteins play a role in defending seeds against Bruchids? - Plant. Physiol. 124: 515-522.

SÉTAMOU M., BERNAL J.S., LEGASPI J.C., MIRKOV T.E., 2002 - Effects of snowdrop lectin (Galanthus nivalis Agglutinin) expressed in transgenic sugarcane on fitness of Cotesia flavipes (Hymenoptera: Braconidae), a parasitoid of the nontarget pest Diatraea saccharalis (Lepidoptera: Crambidae). - Ann. Entomol. Soc. Am. 95: 75-83.

SÉTAMOU M., BERNAL J.S., MIRKOV T.E., LEGASPI J.C., 2003 - Effects of snowdrop lectin on Mexican rice borer (Lepidoptera: Pyralidae) life history parameters. - J. Econ. Entomol. 96: 950-956.

STOGER E., WILLIAMS S., CHRISTOU P., DOWN R.E., GATEHOUSE J.A., 1999-Expression of theinsecticidal lectin from snowdrop (Galanthus nivalis agglutinin; GNA) in transgenic wheat plants: effects on predation by the grain aphid Sitobion avenae. - Mol. Breed. 5: 65-73.

STROBL S., MASKOS K., WIEGAND G., HUBER R., GOMIS-RUTH F., GLOCKSHUBER R., 1998 - A novel strategy for inhibition of $\alpha$-amylases: yellow meal worm $\alpha$-amylase in complex with Ragibi functional inhibitor at 2.5 a resolution. - Struct. 6: 911-921.

SUZUKI K., ISHIMOTO M., KITAMURA K., 1994. - cDNA sequence and deduced primary structure of an alph $\alpha$-amylase inhibitor from a bruchid-resistant wild common bean. - Biochim. Biophys. Acta 1206: 289-291.
TAVAKKOL-AFSHARI J., RAKHSHANDEH H., ZAMANI A., MAHDAVISHAHRI N., GHAZI-ZADEH L., VAHEDI F., et al., 2005 - Cytotoxic effect of Citrullus colocynthis extract on cell line of Hep2 and L929. - Res. J. Hakim. 8: 47-54.

USSUF K.K., LAXMI N.H., MITRA R., 2001 - Proteinase inhibitors: plantderived genes of insecticidal protein for developing insect-resistant transgenic plants. - Curr. Sci. 80: 847-853.

VALENCIA J.A., BUSTILLO A.E., OSSA G.E., CHRISPEELS M.J., 2000 - $\alpha$ Amylases of the coffee berry borer (Hypothenemus hampei) and their inhibition by two amylase inhibitors. - Insect. Biochem. Mol. Biol. 30: 207-213.

VAN DAMME E.J.M., 1998 - Handbook of plant lectins: properties and biomedical applications. - Wiley-Blackwell Publ., New York: 445.

WANG Z., ZHANG K., SUN X., TANG K., ZHANG J., 2005 - Enhancement of resistance to aphids by introducing the snowdrop lectin gene GNA into maize plants. - J. Biosci. 30: 627-38.

WU C.Y., YE Z.B., LI H.X., TANG K.X., 2000 - Genetic transformation of tomato with snowdrop lectin gene (GNA). - Acta. Bot. Sin. 42: 719-23.

YAMADA T., HATTORI K., ISHIMOTO M., 2001 - Purification and characterization of two $\alpha$-amylase inhibitors from seeds of tepary bean (Phaseolus acutifolius A. Gray). - Phytochem. 58: 59-66.

ZHU-SALZMANA K., HAMMENB P.K., SALZMAN R.Y., KOIWA H., BRESSAN R.A., MURDOCK L.L., et al., 2002 - Calcium modulates protease resistance and carbohydrate binding of a plant defense legume lectin, Griffonia simplicifolia lectin II (GSII). - Comp. Biochem. Physiol. Part B 132: 327-334. 